\title{
THE EFFECT OF USING FLASH CARD AND PICTURE STORY IN VOCABULARY MASTERY TO THE SEVENTH GRADER OF SMP PGRI 1 MARGATIGA
}

\author{
by \\ Khoirul Hidayat \\ hidayat_k27@yahoo.com
}

STKIP Kumala Metro Lampung Indonesia

\begin{abstract}
Based on the content standard, junior high school students are hoped to master vocabulary about 1000 words, so they can understand the conversation. But it fact, most of the students in junior high school do not master vocabulary well. So, the teacher should be able to choose a good media to help students to increase their vocabulary. In this case, flash card with picture story is two of media that can be used to transfer vocabulary material for the students.

The objective of this research is to find the significant differences of using flash card with picture story in vocabulary, and to find which medium is more effective to use as media in vocabulary. This research was true experiment design. Pre test and post test were use to collect the data. There are two problems of the study, (1) are there any significant differences between flash card with picture story in vocabulary mastery for the seventh grade students in SMP PGRI 2 Margatiga academic years 2013/2014?, (2) which one is more effective media in vocabulary learning process, is it flash card or picture story at seventh grade of SMP PGRI 2 Margatiga, academic years 2013/2014?. As a source of data, the researcher utilized flash card with picture story to teach vocabulary for the students. The media help students to learn vocabulary easier and more interesting to understand the subject, so their vocabulary would increase.

The result of the research, it was found that the mean score of picture story in pre test is 53,86 , in treatment is 81 , and in post test 85,33 . Meanwhile the mean score of the flash card media in pre test 59,33 , in treatment is 73,5 , and in post test is 80,66 . It means that the student's vocabulary has increased, and there is significant difference of using picture story and flash card in vocabulary instruction, and picture story was more effective to use in vocabulary instruction.
\end{abstract}

Key words: Flash Card, Picture Story, Vocabulary Mastery.

Language is very important role in human life as a tool of communication language is used by people to communicate and interact with others. And someone needs language not only for communication but also for getting science and technology. English is an international language that used as a means of communication all over the world. It has important role to attain social, science, technology, and study. 
English is lingua franca, that is a language used widely for communication between people who do not share the same first (or even second) language, it is an international language so the Indonesia student should be able to use or communicate in English. Therefore English is taught from Junior high school to university as a compulsory subject. But now English has been introduced earlier in elementary school in Indonesia as a local content. (Harmer, 2007)

Teaching second or foreign language is such a complex process that it needs deep attention from the teacher. English as the second of foreign language that is studied by most Indonesians plays a very important role. Every Junior high school in Indonesia puts this language as one of the subjects to be learned.

The students are obligated to achieve four skills namely listening, speaking, reading, and writing, and of the skills should be supported by vocabulary mastery, because beside all skills above, vocabulary as a language component is very important on it. Vocabulary is one of the objects of English teaching in Junior high school. Before studying English completely study vocabulary first.

There is a sense in which learning the vocabulary that language not being able to find the words we need to expressed our selves is the most frustrating experience in speaking after language (Wallace, Teaching Vocabulary and Reading Comprehension, 1988).

There are many languages used in international communication. One of them is English. Indonesian people learn English to communicate in two forms, in spoken and written forms. Indonesian assumes that the English language is a foreign language. So, the Indonesian feels difficult to accept it. If someone wants to learn English very well, she should know four skills. They are listening, speaking, reading, and writing. Besides, she has to master the language components, such as: phonology, grammar, vocabulary, and pronunciation to support the four skills because the skills are very important. 
Vocabulary is one important aspect in learning a foreign language. With a limited vocabulary anyone will also has a limited understanding in terms of speaking, reading, listening, and writing. It is true that it might be impossible to learn a language without mastering vocabulary. Vocabulary is one of the problems confronted by English language learners. Because of the limited vocabulary, the learners cannot communicate to others clearly. Sometimes it is difficult to group the idea transmitted to them. The acquisition of a large number of vocabularies can help the students read, speak, listen, and write. A good vocabulary and ability to use words correctly and effectively can help the students make school work easier and more rewarding, and also many tests that they take in school include vocabulary questions. The more vocabularies they know the better their chance to do well on an English test.

The teacher as a mediator for transferring knowledge to the students must have the capability in teaching vocabulary. Patience will be needed in teaching vocabulary in Junior high school, especially in the first grade of SMP. In this grade, student after fell boring to study and remember many words in their mind, therefore they after consider that learning English is very difficult. Besides facilities and media under communication for study make student not interest with vocabulary, so that teacher is demanded to be more creative use existing facilities.

A vocabulary gradually based on the usage of its frequency in daily (Brown, Teaching by Principles an Interactive Approach to Language Pedagogy, 2007):

a. 1000 words, the student expected who has begun to study English on the third years first can memorize these 1000 words.

b. 2000 words, the student expected who has learn English on the fourth years until sixth years can memorize these 2000 words.

c. 3000 words, the student expected who has learned English in University can memorize these 3000 words. 
Learning vocabulary is something more than memorizing lists of words. It is the teacher's responsibility to determine the appropriate of media in order to the students can find it easier and more useful to communicate". Many students get difficulty in vocabulary. The main difficulties that usually come up are in using appropriate word in contexts, remembering the words that they have learned, and pronouncing the words correctly. At level this is student can dominate 1000 words, but to achieve level finished entire students must achieve $75 \%$ from that determined. For student not yet can achieve teacher pass level give test remedial on condition that that determined (Wallace, 1987).

The material that will be taught to mastery is broken down into small discrete lessons that follow a logical progression. In order to demonstrate mastery over each lesson, students must be able to overtly show evidence of understanding of the material before moving to the next lesson (Brown, 2000).

In this level should student get of best of 1000 words, but practically class student seven SMP PGRI 2 Margatiga only little students known about all of everything exist in around them. Average score final test of the students at seventh grade in SMP PGRI 2 Margatiga, academic years 2012 still low. Because, from the data the researcher get just 30\% students get high score. And 50\% student get medium score and $20 \%$ from all of the students in this grade did not get standard score.

Teaching must planned in such a way that learning will become interesting. It can be done by using songs, movies, stories, drawing, pictures, or group of work or playing games (Celce, 1969).

There are many technique and media to teach vocabulary mastery, but in this research the researcher use picture media, especially picture story and flashcard. Vocabulary mastery in this grade is still low, because of these problems; the teachers must have a good technique and method in teaching vocabulary. Using picture story and flash card media for teaching vocabulary to 
the student are good strategy to overcome these problems. The students feel enjoy and interest to study vocabulary.

Flash card and picture story can be applied to teach in the Junior high school student. The flash card and picture story use concrete object to demonstrate the meaning of new language items. The writer chooses flash card with picture story as the teaching, because flash card and picture story can help students to remember vocabulary about all of everything they look in the market.

\section{METHOD}

Research design is a plan or program made by a researcher, as the activity target that will be done. Research design that will be used in this research is true experimental design. The researcher use pre test and post test control design. In quantitative research, the aim is to determine the relationship between one thing (an independent variable) and another (a dependent or outcome variable) in a population. Quantitative research designs are either descriptive (subjects usually measured once) or experimental (subjects measured before and after a treatment). A descriptive study establishes only associations between variables. An experiment establishes causality (Ary, 2006).

Research design that used in this research is experiment. It is intended to find out the effectiveness or the result of implementing the media in teaching learning. The first part of creating an experiment design is to identify the variables. The quasi-independent variable will be the $\mathrm{x}$-variable, the variable that is manipulated in order to affect a dependent variable. The predicted outcome is the dependent variable which is the $y$-variable. In a time series analysis, the dependent variable is observed over time for any changes that may take place (Creswell, 2008). Once the variables have been identified and defined, a procedure should then be implemented and group differences should be examined.

$$
\frac{G_{1}: T_{1} X_{1} X_{1} \ldots T_{2}}{G_{2}: T_{1} X_{2} X_{2} \ldots T_{2}}
$$


$\mathrm{G}_{1}$ : Experiment class

$\mathrm{G}_{2}$ : Control class

T1 : Pre test, it will be given before treatment

$\mathrm{X}_{1}$ : Treatments, it will be given after pre test of vocabulary by using picture story media

$\mathrm{X}_{2}$ : Treatments, it will be given after pre test of vocabulary by using flash card media

T2 : Post test, it will be given after the treatment.

\section{Population}

The population is a sample in a research. A population is the group to which a research would like the result of a study to be generalize". A defined population has at least one characteristic that differentiates it from other group (Gay, 1990).

The research uses purposive technique to get the populations. The population of the research is students' class seventh grade of SMP PGRI 2 Margatiga in academic year 2013/2014, which consists of 95 students and divided into 3 classes. They were as follow Class VIIB: 33 students, Class VIIC: 30 students, Class VIID: 32 students.

The researcher chooses these classes because class VIIB, VIIC and VIID has same level, there are different level with VIIA class. It is a excel class and for VII E, F, $\mathrm{G}$ and $\mathrm{H}$ are regular class.

\section{Sample}

A good sample is one that is representative of the population from which it was selected". Sample is a part of population that has all main characteristic from 
population. Sample is the subject of the population that will be taken by researcher to be researched (Gay, 1990).

The sample technique in this research is stratified random sampling. The first, the researcher divides the students into three groups namely the smartest, medium, and weak students. Then, random sampling will be used to choose the students who will be sample in this research. The interpretation of this sample will be done with the consideration that characteristic of every students have different, although they sat at the same semester and got the same information. Class will be chosen by researcher in a purposive random sampling; from three classes the researcher only chosen two classes. There are 30 students of class VIIC and 32 students of class VIID. Because these classes have same level, there is a favorite to win level. The researcher not chosen class VIIB because this class has good score compared class VIIC and VIID.

This research has done in SMP PGRI 2 Margatiga with the population entire grade seven, and for the samples are VIIC as experiment class and VIID as control class. The classes were taken by simple random sampling at seventh grade. The class was taken by stratified random sampling to apply this media the researcher use the data from the researcher as based data to divide the students in three part as high, average, and low. By doing this research, hopefully the researcher would know the effectiveness between picture story media and flash card media in instructional vocabulary.

The implementation covered try out and test. The try out was done at the seventh grade or class VIIB. The try out was help to get the validity and reliability test. If the test has been valid and reliable, so the test can use to experiment, the researcher used test as instrument. Before doing the test, the instrument should have been known about its validity level. The measurement of the vocabulary test items, the researcher used content validity through tryout test. The researcher gave tryout once for 32 students, which consist of 30 items of multiple choice, because after calculated, the test has been reliable, it means that the instrument has valid. 
So, the researcher used the tryout test to be tested after the researcher eliminates 10 items from try out test. The researcher used 20 items to pre test and post test.

Reliability of the test was needed in order that the test could be used. The writer used Product moment formula to know the reliability. The result of the tryout test was split into odd and even numbers. The both of them were correleted by used Spearman-brown formula.

After calculated by using product moment formula, it was gotten 0.63 in the try out. There was the correlation between odd and even items score and from the calculation that by using by Spearmrn Brown, the first gotten $r_{11}=0,77$. If the result consulting to the $\mathrm{r}$ score, it means that the result has very high interpretation. So, the test was reliable and could be used for the the research.

The researcher used Product moment formula to know the difficulty level of test item. The researcher used the difficult level of test item to know difficult and easy level of the test item. The researcher has 30 items test, and all of items have different level. The fist level is difficult level; there are number 14, 21, and 30. The second level is average; there are numbers $3,4,5,6,7,8,9,10,11,12$, $13,15,17,18,19,20,22,23,24,25,27,28$, and 29. And the tried level is easy level; there are 1, 2, 16, and 26.

Researcher gave pre test before giving the treatments. The pre test was give to 30 students which consist of 30 items test. The students were come from 15 students of VIIC and 15 students of VIID. In experiment class the highest score was 70 and the lowest was 35 which had a mean 53,86. Meanwhile, in control class the highest score was 70 and the lowest was 45 which had a mean 59,33 From the data, it was known that most of them had not mastered vocabulary well.

In experimental class, for the first treatment, the highest score was 90, and the lowest score was 60.In the second treatment, the highest score was 95, and the lowest score was 65 , and in the third treatment, the highest score was 95, and the 
lowest score was 70 . The total score of the first treatment until the third treatment in experimental class was 3645 with the mean 81.

In other hand, in control class the total score of the first treatment until third treatment was 3310 with the mean 73,5. For the first treatment, the highest score was 85 , and the lowest score was 60 . For the second treatment, the highest score was 90 , and the lowest score was 65 , and for the third treatment, the highest score was 95, and the lowest score was 70 .

The post test was given after the researcher gave the treatment in the three meeting. The post-test was given to both of classes in order to know the students' vocabulary mastery after they received the treatments. The post test held simultaneously in 30 minutes. The pre test and post test had similar type. There were 20 multiple choice each treatment.

\section{CONCLUSION}

Based on the result of the research,flash cardand picture story has increased students vocabulary mastery at the first grade of SMP PGRI 2 Margatiga. It is showed from their result of pre-test and post-test. The students' vocabulary had increased based on the changed that happening on themselves when they listened and saw picture story media, and when they saw flash card. Most of changes were caused by the media; sometimes they memorized and spoke the word.

From the data, researcher concluded that there was significant difference of using flash card and picture story in student's vocabulary mastery instruction for the seventh grade at SMP PGRI 2 Margatiga. It was proved from the data that in experiment class who was taught by using picture story media, the total treatment mean score was 81 and in control class who was taught by using flash card had the total treatment mean score 73,5. 
Then, it was found that picture story more effective or equal to flash card to use as media in instruction vocabulary for the students in Junior High School, especially in SMP PGRI 2 Margatiga. It was proved from the post test data that in experiment class, it had post test mean score 85,33 and in control class, it had mean score 80,66.

Flash card and picture story as media in vocabulary instruction had contribution and significant effect for both students and the teacher. The students enjoyed and they were fun in accepting information especially the new experience in learn vocabulary, while the teacher was easier in transferring material to learn vocabulary. Besides, the students more understood about vocabulary belonging to its indicators. So, they could write and speak better than before. Based on the result and discussion, the researcher concluded that picture story media and flash card media has effective to teach vocabulary material for the students grade seventh in Junior High School, although they have different in students achievement.

\section{REFERENCES}

Ary, D. (2006). Introduction to Reasearch in Education. USA: Wadsworth.

Brown, H. D. (2000). Principle of Language Learning and Interactive Approach to Language Pedagogy (2 ed.). NY: Person Longman.

Brown, H. D. (2007). Teaching by Principles an Interactive Approach to Language Pedagogy. USA: Person Longman.

Celce, M. (1969). Teaching English as a Second or Foreign Language. Boston: Heine.

Creswell, J. (2008). Educational Research Planning, Conducting, and Evaluating Quantitative and Qualitative Research. England: Person Longman.

Gay, L. R. (1990). Educational Research: Competencies for Analysis and Application. New York: Merrill. 
Harmer, J. (2007). The Practice of English Language Teaching. England: Person Longman.

Wallace, M. (1987). Teaching Vocabulary and Reading Comprehension (2nd ed.). London: Briddles.

Wallace, M. (1988). Teaching Vocabulary and Reading Comprehension. London: Briddles. 